\title{
Examination of polymorphism in hybrid wheat by using amplified fragment length polymorphism marker
}

\author{
M. Ejaz, Z. Gaisheng, Z. Quidi, W. Qunzhu and Z. Huiyan \\ College of Agronomy, Northwest A\&F University, Yangling, Shaanxi, China \\ Corresponding author: Z. Gaisheng \\ E-mail: zhanggsh@public.xa.sn.cn
}

Genet. Mol. Res. 13 (4): 10076-10085 (2014)

Received June 11, 2013

Accepted August 15, 2014

Published December 4, 2014

DOI http://dx.doi.org/10.4238/2014.December.4.2

\begin{abstract}
To investigate the polymorphism of two groups of male sterile lines and their maintainer lines, we used amplified fragment length polymorphism markers. Of the 64 primer pairs, five reproducibly demonstrated polymorphism. Group I had 27 polymorphic bands, and Group II had 24 polymorphic bands. The maximum number of polymorphic bands was produced by line 2 (18 polymorphic bands) followed by line 7 ( 15 polymorphic bands). Of the five primer pairs, the highest number of polymorphic bands was produced by primer pair E1/ M4, and the smallest number of polymorphic bands was produced by primer pair E1/M2. DNA fingerprinting, germplasm characterization, and cytogenetic research have especially been emphasized in studies of bread wheat; these methods are highly useful to select appropriate accessions for plant improvement and hybridization through molecular breeding approaches to evolve suitable safeguard strategies.
\end{abstract}

Key words: Amplified fragment length polymorphism marker; Polymorphism; Male sterile lines; Triticum aestivum 


\section{INTRODUCTION}

Wheat (Triticum aestivum) is the most important cereal of the world, and it exceeds every other grain crop in acreage and production. With the introduction of semi-dwarf, photosensitive, fertilizer-responsive, and high-yielding varieties of wheat, the interest in hybrid wheat as a productivity-boosting option has followed an uneven route. Early interest, following the discovery of the cytoplasmic male sterility system (Wilson and Ross, 1962), was dominated by the advent of semi-dwarf wheat as a successful productivityenhancing scheme.

Molecular tactics for plant breeding have made significant progress and are applied through the use of 2 main but utterly different approaches; each approach accelerates the process of plant breeding. In the first plan, a variety of transgenic crops are produced that carry genes, which a plant breeder previously failed to introduce using the available conventional methods. In the second approach, numerous molecular markers that are narrowly linked to abundant traits of economic importance have been defined (Caetano-Anollés and Gresshoff, 1997) and permit indirect selection for desirable traits in early segregating generations at the seedling stage. This will save time, resources, and energy that are needed not only for raising large segregating populations for several generations but also for estimating the strictures that are used for direct selection. Various molecular markers are available (Mohan et al., 1997; Gupta et al., 1999a), and efforts are also being made to categorize the most effectual and costeffective markers that can be used by plant breeders.

The study of phylogenetic and taxonomic relationships requires a flexible and reliable marker system that is able to detect high levels of polymorphism. Because of their effectiveness and potential for robotics, polymerase chain reaction (PCR)-based methods are attractive for this purpose (Rafalski and Tingey, 1993). Amplified fragment length polymorphism (AFLP) markers (Zabeau and Vos, 1993) do not require prior knowledge about the genomic makeup of the organism; additionally, AFLP markers are flexible, reliable, and illustrate high levels of polymorphism, which relies on the restriction digestion of genomic DNA and subsequent polymerase chain reaction (PCR) amplification. Assessing the genetic diversity among wheat cultivars with AFLP fingerprinting has also proven to be accurate (Barrett and Kidwell, 1998).

This study was designed to test the fidelity of wheat male sterile lines, their behavior with the maintainer lines (A-90-110 and A-8222), and their polymorphism using AFLP marker technology at Key Laboratory of Crop Heterosis of Shaanxi Province, Northwest A\&F University, Yangling, China.

\section{MATERIAL AND METHODS}

\section{Plant material}

In this research, the behavior of male sterile lines $[\mathrm{ms}(\mathrm{K})-77(2), \operatorname{ms}(\mathrm{V})-77(2)$, $\mathrm{ms}(\mathrm{Ven})-77(2), \mathrm{ms}(\mathrm{B})-77(2)$, and $\mathrm{ms}(\mathrm{S})-77(2)]$ with their maintainer lines [A-90-110 and A-8222] was assessed. The samples were divided into two (2) groups [Group I (1 to 6) and Group II (7 to 12) of wheat (Triticum aestivum) according to the maintainer line, and all the lines are heterocytoplasmic with the same nucleus (Table 1). These sterile lines were derived 
from recurrent backcrosses after twenty (20) generations. The seed was soaked in water for $6 \mathrm{~h}$; under standard agronomic culture practices, the sprouted wheat seeds were grown in plastic pots over a period of 3 weeks at room temperature.

\begin{tabular}{|c|c|c|c|c|c|}
\hline \multirow[t]{2}{*}{ Line No. } & \multicolumn{3}{|c|}{ Wheat accessions } & \multirow[t]{2}{*}{ Fertility status } & \multirow[t]{2}{*}{ Group } \\
\hline & Code name & Male sterile lines & Type & & \\
\hline 1 & K-90-110 & $\mathrm{ms}(\mathrm{K})-77(2)$ & Aegilops kotschyi & S-line & \multirow[t]{6}{*}{ I Maintainer line A-90-110 } \\
\hline 2 & V-90-110 & $\mathrm{ms}(\mathrm{V})-77(2)$ & Aegilops variabilis & S -line & \\
\hline 3 & Ven-90-110 & ms(Ven)-77(2) & Aegilops ventricosa & $\mathrm{S}$-line & \\
\hline 4 & B-90-110 & $\mathrm{ms}(\mathrm{B})-77(2)$ & Aegilops bicornis & S -line & \\
\hline 5 & S- $90-110$ & $\mathrm{~ms}(\mathrm{~S})-77(2)$ & Triticum spelta & S-line & \\
\hline 6 & A-90-110 & - & Triticum aestivum & F-line & \\
\hline 7 & K-8222 & $\mathrm{ms}(\mathrm{K})-77(2)$ & Aegilops kotschyi & S-line & \multirow[t]{6}{*}{ II Maintainer line A- 8222} \\
\hline 8 & V-8222 & $\mathrm{ms}(\mathrm{V})-77(2)$ & Aegilops variabilis & S-line & \\
\hline 9 & Ven-8222 & ms(Ven)-77(2) & Aegilops ventricosa & S-line & \\
\hline 10 & B-8222 & $\mathrm{ms}(\mathrm{B})-77(2)$ & Aegilops bicornis & S-line & \\
\hline 11 & S-8222 & $\mathrm{ms}(\mathrm{S})-77(2)$ & Triticum spelta & S-line & \\
\hline 12 & A- 8222 & - & Triticum aestivum & F-line & \\
\hline
\end{tabular}

\section{Isolation of genomic DNA}

Genomic DNA was isolated from individual plants following the modified cetyl trimethyl ammonium bromide (CTAB) protocol of (Murray and Thompson, 1980). About $0.5 \mathrm{~g}$ fresh fledgling leaves was pounded systematically with water and blotted dry. The leaves were homogenized to a fine powder in liquid nitrogen. The pulverized powder was transferred to $2 \mathrm{~mL}$ pre-warmed DNA extraction buffer [100 mM Tris- $\mathrm{HCl}, \mathrm{pH} 8.0,20 \mathrm{mM}$ ethylene diamine tetra acetic acid (EDTA), $\mathrm{pH} 8.0,1.4 \mathrm{M} \mathrm{NaCl}, 2 \% \mathrm{CTAB}(\mathrm{w} / \mathrm{v})$, and $0.2 \%$ $\beta$-mercaptoethanol]. The homogenate was mixed thoroughly by inverting the tube several times and incubated at $65^{\circ} \mathrm{C}$ for $60 \mathrm{~min}$. During incubation, the contents of the tubes were mixed many times by inversion. An equal volume of chloroform:isoamyl alcohol (24:1) was added and mixed thoroughly by gently inverting the tubes several times. After centrifugation at $12,000 \mathrm{rpm}$ for $10 \mathrm{~min}$ at room temperature, the upper aqueous phase was transferred to a fresh tube, and the step was repeated. RNA was digested from the samples with $10 \mu \mathrm{g} / \mu \mathrm{L}$ DNase-free RNase enzyme [Tian Gen (Chinese Company)] and incubated at $37^{\circ} \mathrm{C}$ for $30 \mathrm{~min}$. DNA was precipitated by adding $1 / 10$ volume $3 \mathrm{M}$ sodium acetate, $\mathrm{pH} 5.2$, and 2 volumes ethanol and storing at $-70^{\circ} \mathrm{C}$ for $60 \mathrm{~min}$. The DNA was pelleted by centrifugation at $12,000 \mathrm{rpm}$ for $15 \mathrm{~min}$ at $4^{\circ} \mathrm{C}$. The white pellets (DNA) were washed twice with $70 \%$ ethanol and once with $96 \%$ ethanol, air-dried, and dissolved in Tris-EDTA (TE) buffer (10 mM Tris-HCl, pH 8.0, $1 \mathrm{mM}$ EDTA, pH 8.0). The total DNA was stored at $-20^{\circ} \mathrm{C}$ for further use. Genomic DNA was separated on $1.5 \%$ agarose gels and visualized by ethidium bromide staining (Figure 1).

\section{AFLP marker analysis}

AFLP analysis was performed using kits from Thermo Scientific China and following manufacturer instructions (Vos et al., 1995). 


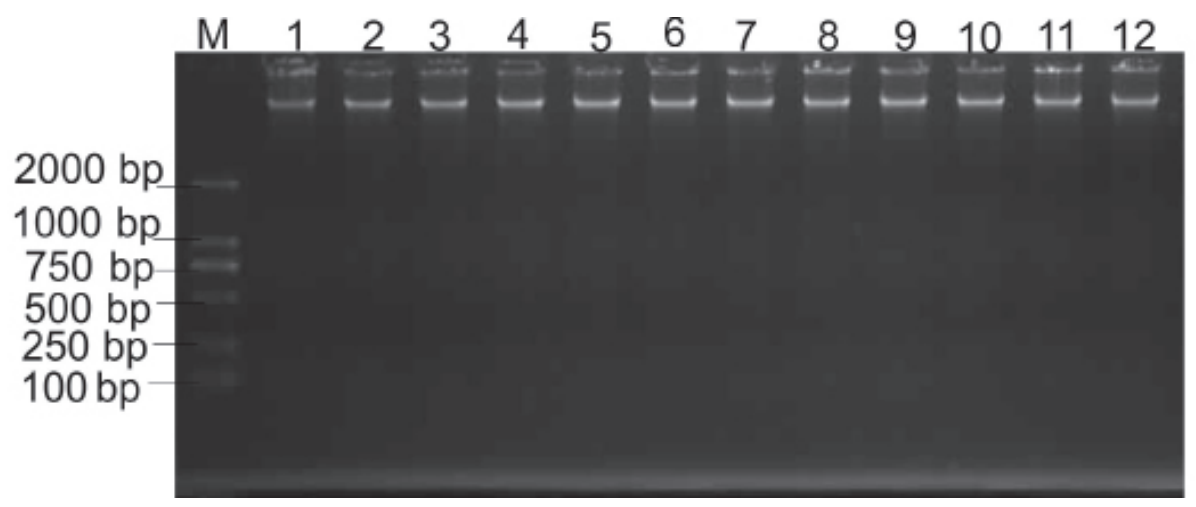

Figure 1. Results of genomic DNA from wheat accessions. Lane $M=$ Marker (2000 bp); lane 1=V-90-110; lane $2=\mathrm{K}-90-110$; lane $3=\mathrm{Ven}-90-110$; lane $4=\mathrm{B}-90-110$; lane $5=\mathrm{S}-90-110$; lane $6=\mathrm{A}-90-110$; lane $7=\mathrm{K}-8222$; lane $8=\mathrm{V}-8222$; lane $9=\mathrm{Ven}-8222$; lane $10=\mathrm{B}-8222$; lane $11=\mathrm{S}-8222$; lane $12=\mathrm{A}-8222$.

\section{Digestion and ligation}

Genomic DNA (250 ng) was digested with EcoRI and MseI enzymes (2.5 U each) for $180 \mathrm{~min}$ at $37^{\circ} \mathrm{C}$ and $150 \mathrm{~min}$ at $65^{\circ} \mathrm{C}$ in a $25-\mu \mathrm{L}$ reaction volume, and the enzymes were heat-inactivated by incubating the tubes at $70^{\circ} \mathrm{C}$ for $15 \mathrm{~min}$. The DNA fragments were ligated to appropriate adapters using T4 DNA ligase $(1 \mathrm{U})$ and $24 \mu \mathrm{L}$ EcoRI and MseI adapter ligation mixture by incubating at $20^{\circ} \mathrm{C}$ for $720 \mathrm{~min}$.

\section{Non-selective amplification}

Ligated DNA mixture was pre-amplified using adapter primers with $\mathrm{A}$ and $\mathrm{C}$ selective nucleotides (i.e., EcoRI+A and $M s e \mathrm{I}+\mathrm{C}$ ) in a final volume of $50 \mu \mathrm{L}$ (Table 2). The PCR cycling parameters were the following: $94^{\circ} \mathrm{C}$ for $30 \mathrm{~s} ; 32$ cycles of $94^{\circ} \mathrm{C}$ for $30 \mathrm{~s}, 56^{\circ} \mathrm{C}$ for 45 $\mathrm{s}$, and $72^{\circ} \mathrm{C}$ for $120 \mathrm{~s}$; and a final cycle of $72^{\circ} \mathrm{C}$ for $10 \mathrm{~min}$.

\section{Selective amplification}

For selective amplification, primers (EcoRI and $M s e \mathrm{I}$, Table 2) were mixed with $5 \mu \mathrm{L}$ 50 -fold diluted pre-amplified DNA, and PCR buffer in a final volume of $20 \mu \mathrm{L}$. The following PCR cycling parameters were used for selective amplification: $94^{\circ} \mathrm{C}$ for $30 \mathrm{~s} ; 94^{\circ} \mathrm{C}$ for 30 $\mathrm{s}, 65^{\circ} \mathrm{C}$ for $30 \mathrm{~s}$, and $72^{\circ} \mathrm{C}$ for $60 \mathrm{~s}$, and the annealing temperature was lowered by $0.7^{\circ} \mathrm{C}$ per cycle for 12 cycles; and 23 cycles at $94^{\circ} \mathrm{C}$ for $30 \mathrm{~s}, 56^{\circ} \mathrm{C}$ for $30 \mathrm{~s}$, and $72^{\circ} \mathrm{C}$ for $60 \mathrm{~s}$.

\section{Analysis of the selective PCR products}

The amplified products were analyzed on $6 \%$ denaturing polyacrylamide gels in $1 \mathrm{x}$ Tris, boric acid, and EDTA buffer. DNA samples were electrophoresed (50 W) for $180 \mathrm{~min}$. After electrophoresis, gels were silver stained as described by Bassam et al. (1991). 
Table 2. Amplified fragment length polymorphism (AFLP) primer sequences.

\begin{tabular}{ll}
\hline Code & Primer sequence \\
\hline EAF & 5'-CTCGTAGACTGCGTACC-3' \\
EAR & 5'-AATTGGTACGCAGTCTAC-3' \\
MAF & 5'-GACGATGAGTCCTGAG-3' \\
MAR & 5'-TACTCAGGACTCAT-3' \\
E $(E c o R I+A)$ & 5'-GTAGACTGCGTACCAATTCA-3' \\
M $(M s e I+C)$ & 5'-GACGATGAGTCCTGAGTAAC-3' \\
E1 & 5'-GTAGACTGCGTACCAATTCAAC-3' \\
M1 & 5'-GACGATGAGTCCTGAGTAACAA-3' \\
M2 & 5'-GACGATGAGTCCTGAGTAACAC-3' \\
M3 & 5'-GACGATGAGTCCTGAGTAACAG-3' \\
M4 & 5'-GACGATGAGTCCTGAGTAACAT-3' \\
M6 & 5'-GACGATGAGTCCTGAGTAACTC-3' \\
\hline
\end{tabular}

\section{RESULTS}

We analyzed the behavior of two groups [Group I ( 1 to 6$)$ and Group II (7 to 12)] of five male sterile lines and their maintainer line (A-90-110 and A-8222) (Table 1). We used the AFLP technique for the selective amplification of restriction fragments from digested genomic DNA (Vos et al., 1995). All AFLP marker primer combinations were tested, and 5 primer pairs were selected based on their identification of polymorphism (Table 2). AFLP, a PCR-based fingerprinting technology, is stringent, versatile, robust, and quantitative (Zabeau and Vos, 1993).

The wheat accessions produced 51 polymorphic bands (group I and group II produced 24 and 27 polymorphic bands, respectively) with 5 primer pair combinations. The maintainer line 12 (A-8222) showed polymorphism and produced 10 polymorphic bands. We considered only clear and bright bands in our analysis of polymorphism.

\section{Primer pair E1/M1}

Line 2 (V-90-110) and 7 (K-8222) each produced 4 polymorphic bands from amplification with primer pair E1/M1. The largest band of $700 \mathrm{bp}$ was produced by line 7 , while line 2 produced a band that was $400 \mathrm{bp}$. The maintainer line 12 produced 2 polymorphic bands that were 200 and $150 \mathrm{bp}$ (Figure 2).

\section{Primer pair E1/M2}

The E1/M2 primer combination produced bands that ranged from 70 to $700 \mathrm{bp}$. The highest number of bands was produced by line 2. Of the 9 bands that were produced, 6 were polymorphic bands that ranged from 50 to $500 \mathrm{bp}$. Line 7 had polymorphic bands of 600 and $270 \mathrm{bp}$, while its maintainer line produced had bands of 210 and $160 \mathrm{bp}$ (Figure 3).

\section{Primer pair E1/M3}

Line 7 produced 3 clear polymorphic bands that ranged from 130 to $600 \mathrm{bp}$ from primer pair E1/M3. The maintainer line 12 produced 2 polymorphic bands of 160 and 210 bp (Figure 4). 


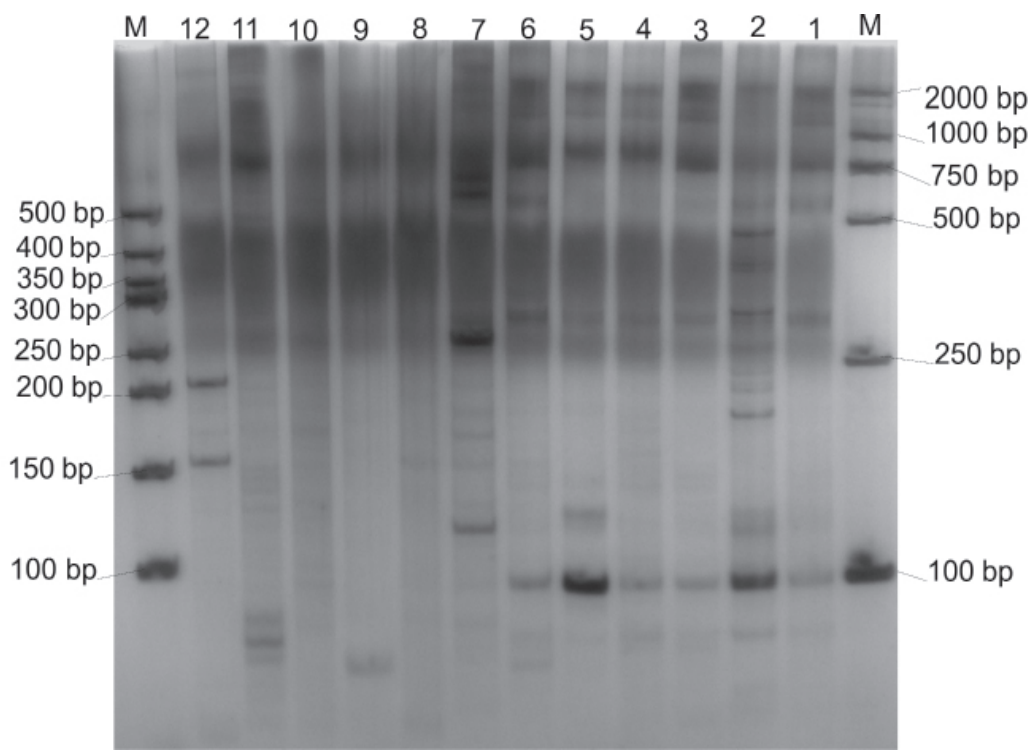

Figure 2. Results of AFLP marker primer combination E1/M1 from wheat accessions. Lane $M=$ Marker (2000 bp); lane 1 = V-90-110; lane 2 = K-90-110; lane 3 = Ven-90-110; lane 4 = B-90-110; lane 5 = S-90-110; lane $6=$ A-90-110; lane $7=\mathrm{K}-8222$; lane $8=\mathrm{V}-8222 ;$ lane $9=\mathrm{Ven}-8222 ;$ lane $10=\mathrm{B}-8222 ;$ lane $11=\mathrm{S}-8222 ;$ lane $12=$ A-8222; lane $M=$ Marker (500 bp).

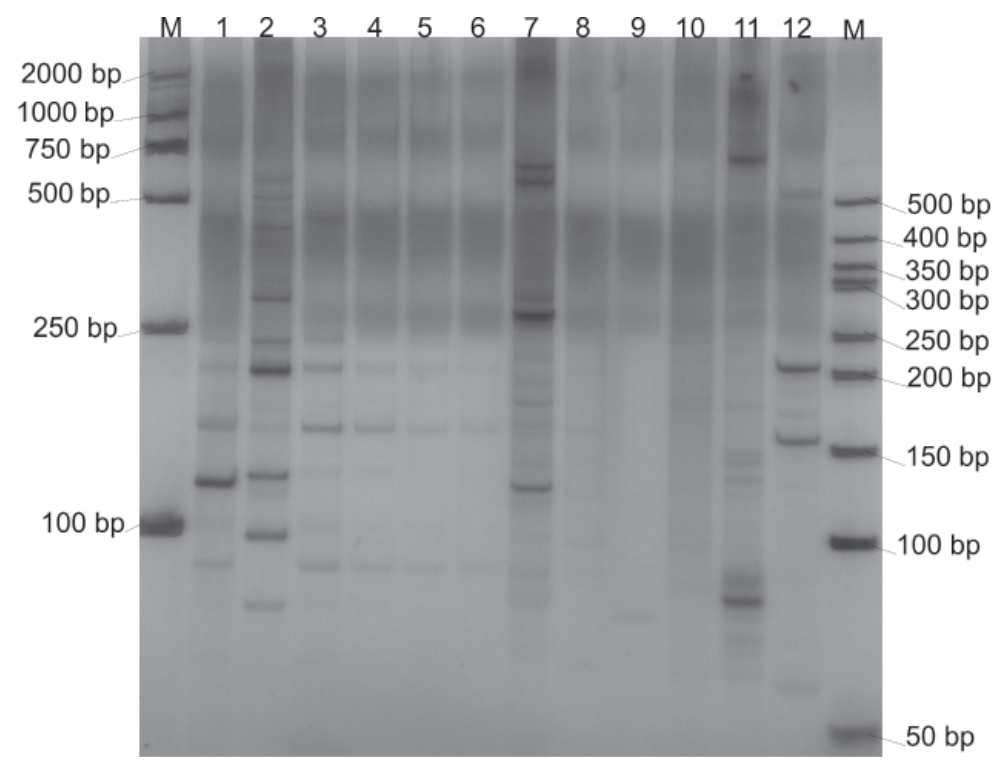

Figure 3. Results of AFLP marker primer combination E1/M2 from wheat accessions. Lane $M=$ Marker (2000 bp); lane 1 = V-90-110; lane 2 = K-90-110; lane 3 = Ven-90-110; lane 4 = B-90-110; lane 5 = S-90-110; lane $6=$ A-90-110; lane $7=\mathrm{K}-8222$; lane $8=\mathrm{V}-8222 ;$ lane $9=\mathrm{Ven}-8222 ;$ lane $10=\mathrm{B}-8222 ;$ lane $11=\mathrm{S}-8222 ;$ lane $12=$ A-8222; lane $M=$ Marker (500 bp). 


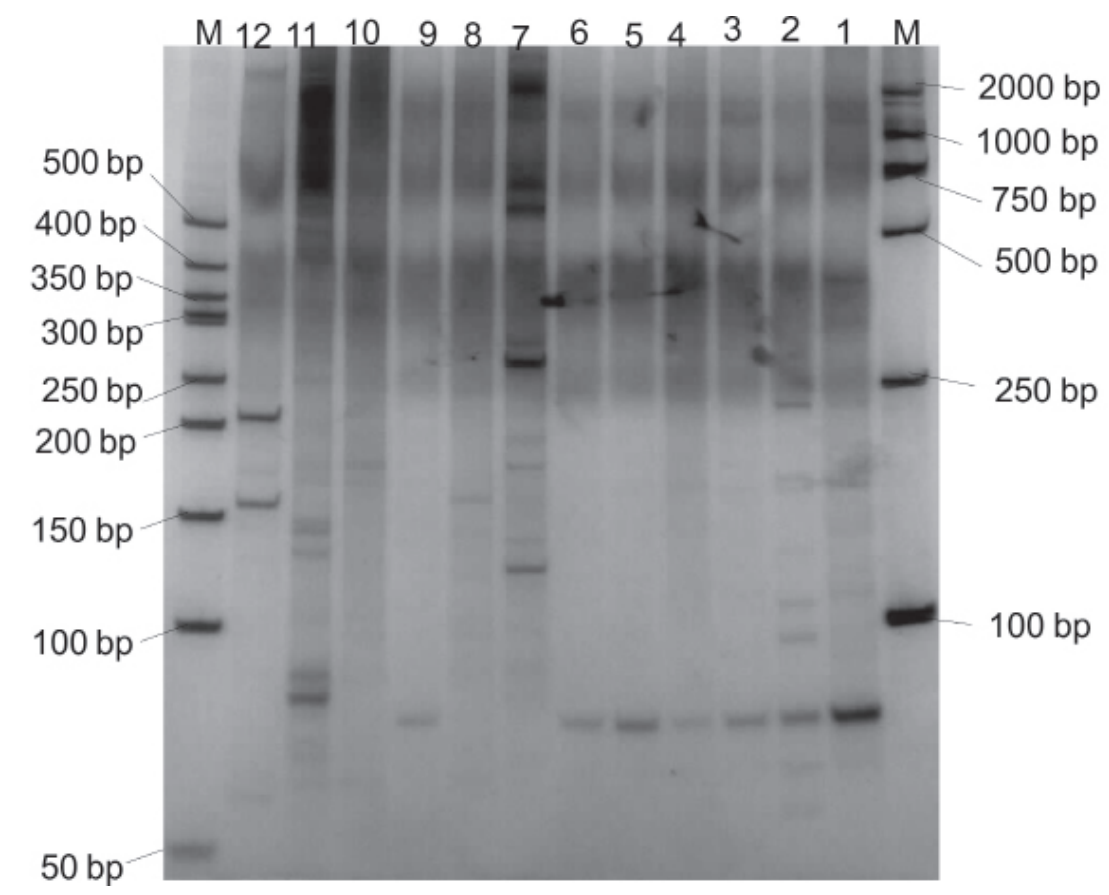

Figure 4. Results of AFLP marker primer combination E1/M3 from wheat accessions. Lane $M=$ Marker (2000 bp); lane 1 = V-90-110; lane 2 = K-90-110; lane 3 = Ven-90-110; lane $4=\mathrm{B}-90-110$; lane $5=\mathrm{S}-90-110$; lane $6=$ $\mathrm{A}-90-110$; lane $7=\mathrm{K}-8222$; lane $8=\mathrm{V}-8222$; lane $9=\mathrm{Ven}-8222$; lane $10=\mathrm{B}-8222$; lane $11=\mathrm{S}-8222$; lane $12=$ A-8222; lane $M=$ Marker (500 bp).

\section{Primer pair E1/M4}

Line 2 produced the most polymorphic bands using primer pair E1/M4 (5 bands: 120 , $140,200,260$, and $500 \mathrm{bp}$ ), followed by line 5 , which produced 4 polymorphic bands of 70 , 250, 300, and $400 \mathrm{bp}$. Line 12 produced 2 polymorphic bands (210 and $160 \mathrm{bp}$ ), and line 7 produced only 1 polymorphic band of $280 \mathrm{bp}$ (Figure 5).

\section{Primer pair E1/M6}

Using primer pair E1/M6, line 7 produced the most polymorphic bands (4 bands) and was followed by line 2, which produced 3 polymorphic bands of 400, 180, and $170 \mathrm{bp}$. Maintainer line 12 produced 2 polymorphic bands of 210 and $160 \mathrm{bp}$ (Figure 6).

The accessibility of many different restriction enzymes and analogous primer combinations provides a great deal of flexibility and assists the direct manipulation of AFLP fragment generation for defined applications. The power of the AFLP methodology is based on the molecular genetic variations that exist between closely related species, varieties, or cultivars (Keim et al., 1997). 


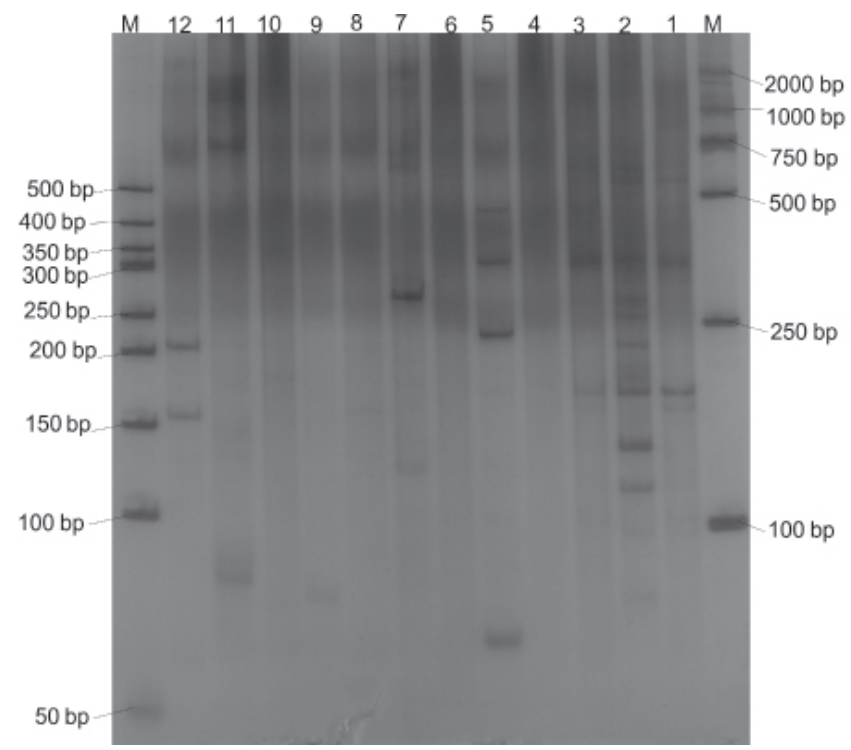

Figure 5. Results of AFLP marker primer combination E1/M4 from wheat accessions. Lane $M=$ Marker (2000 $\mathrm{bp);} \mathrm{lane} 1$ = V-90-110; lane 2 = K-90-110; lane 3 = Ven-90-110; lane 4= B-90-110; lane 5= S-90-110; lane $6=$ A-90-110; lane $7=\mathrm{K}-8222$; lane $8=\mathrm{V}-8222$; lane $9=\mathrm{Ven}-8222$; lane $10=\mathrm{B}-8222 ;$ lane $11=\mathrm{S}-8222 ;$ lane $12=$ A-8222; lane $M=$ Marker (500 bp).

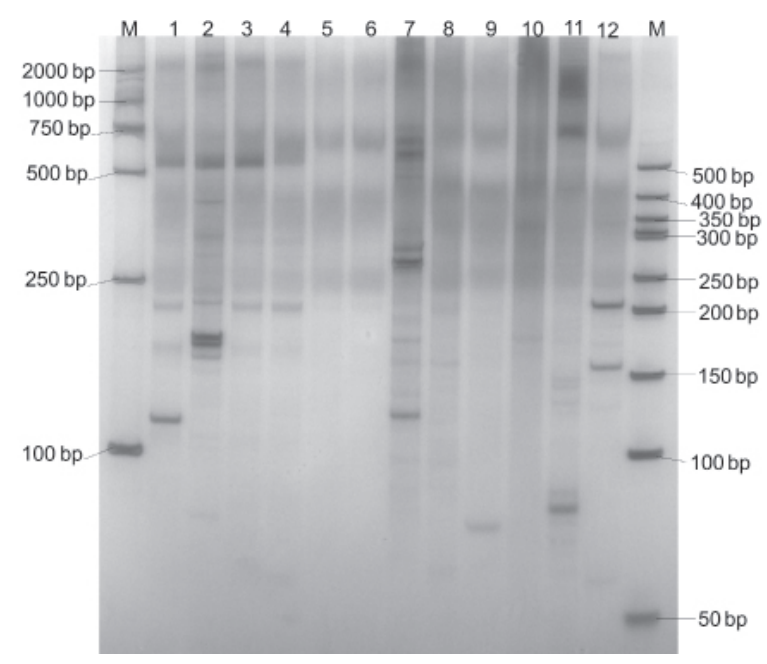

Figure 6. Results of AFLP marker primer combination E1/M6 from wheat accessions. Lane $M=$ Marker (2000 bp); lane 1 = V-90-110; lane 2 = K-90-110; lane 3 = Ven-90-110; lane 4 = B-90-110; lane 5 = S-90-110; lane $6=$ A-90-110; lane 7= K-8222; lane 8=V-8222; lane $9=\mathrm{Ven}-8222$; lane $10=\mathrm{B}-8222$; lane $11=\mathrm{S}-8222$; lane $12=$ A-8222; $M=$ Marker (500 bp). 


\section{DISCUSSION}

Crop advancement involves selective breeding and hybridization using controlled pollination of plants. The development of biotechnology tools changed traditional plant breeding into a far more precise science. Marker-assisted selection allows plants to be sorted at the juvenile stage from an early generation and can assist in selecting suitable parents by examining the variation in genetic origin and the presence of desired traits in different lines. Instead of selecting for the gene itself, the molecular markers closely linked to the genes of interest are used to monitor the incorporation of the desirable alleles from the subscriber source (Dudley, 1993).

The largest number of polymorphic bands was produced by the primer combination E1/M4 (12 bands), and the smallest number of polymorphic bands was produced by E1/M3 (7 bands). The complexity of AFLP fingerprints is generally manipulated by adjusting the selective nucleotides or the CG content of the primer extensions (Thomas et al., 1995; Cervera et al., 1996). It is known that many plant genomes are AT rich; therefore, increasing the GC content of the primers may result in fewer bands (Keim et al., 1997; Qi and Lindhout, 1997). About $50 \%$ of the polymorphic loci were produced with primers with $50 \%$ CG content, signifying the polymorphic nature of the AT-rich regions of the genome (Röder et al., 1995). Line 2 showed the highest polymorphism and produced 18 polymorphic bands; line 7 followed with 15 polymorphic bands. The high AT content, which is generally found in many plant genomes, necessitated the careful selection of primer extensions (Thomas et al., 1995; Cervera et al., 1996). Increasing the GC content of the primers could result in fewer fragments (Keim et al., 1997; Qi and Lindhout, 1997).

Some advantages of DNA markers are that they are not biased by the environment, are expressed in all tissues, and can be distinguished at all stages of plant growth. A large number of markers have been developed, and a number of these were reviewed (Gupta et al., 1999b; Hartl, 2000). The applications of DNA markers are copious; they can be used for gene tagging and genome mapping. Mapping involves putting markers in order, indicating the relative genetic distances between them, and assigning them to linkage groups on the basis of the recombination values from all the pair-wise combinations (Jones et al., 1997).

\section{CONCLUSION}

Many DNA markers have been developed that are powerful tools for successful cereal breeding and hybridization. The promise of marker-assisted selection in crop breeding remains, but realizing practical benefits is taking longer than expected. Only close interactions between breeders and biotechnologists will accelerate the effective implementation of markerassisted selection in cereal breeding programs. The AFLP technique is expensive, technically difficult, laborious, and time consuming to set up; however, it is reliable, reproducible, and highly informative (Powell et al., 1996; McGregor et al., 2000).

\section{ACKNOWLEDGMENTS}

Research supported by the National High Technology Research and Development Program of China (\#2011AA10A106), the National Natural Science Foundation of China 
(\#31071477, \#31371697), and the Key Scientific and Technological Innovation Special Projects of Shaanxi Province "13115” (\#2010ZDKG-68).

\section{REFERENCES}

Barrett BA and Kidwell KK (1998). AFLP-based genetic diversity assessment among wheat cultivars from the Pacific Northwest. Crop Sci. 38: 1261-1271.

Bassam BJ, Caetano-Anolles G and Gresshoff PM (1991). Fast and sensitive silver staining of DNA in polyacrylamide gels. Anal. Biochem. 196: 80-83.

Caetano-Anollés G and Gresshoff PM (1997). DNA Markers: Protocols, Applications and Overviews. John Wiley \& Sons, New York.

Cervera MT, Gusmão J, Steenackers M, Peleman J, et al. (1996). Identification of AFLP molecular markers for resistance against Melampsora larici-populina in Populus. Theor. Appl. Genet. 93: 733-737.

Dudley JW (1993). Molecular markers in plant improvement: manipulation of genes affecting quantitative traits. Crop Sci. 33: 660-668.

Gupta PK, Varshney RK, Sharma PC and Ramesh B (1999a). Molecular markers and their applications in wheat breeding. Plant Breed. 118: 369-390.

Gupta PK, Baylan HS, Sharma PC and Ramesh B (1999b). Development of molecular markers for wheat breeding at Meerut, a center for the Wheat Biotechnology Network in India. Annu. Wheat Newsl. 45: 78-82.

Hartl DL (2000). A primer of population genetics. 3rd edn. Sinauer Associates, Sunderland, 1-58.

Jones N, Ougham H and Thomas H (1997). Markers and mapping: we are all geneticists now. New Phytol. 137: 165-177.

Keim P, Schupp JM, Travis SE and Clayton K (1997). A high-density soybean genetic map based on AFLP markers. Crop Sci. 37: 537-543.

McGregor CE, Lambert CA, Greyling MM and Louw JH (2000). A comparative assessment of DNA fingerprinting techniques (RAPD, ISSR, AFLP and SSR) in tetraploid potato (Solanum tuberosum L.) germplasm. Euphytica 113: 135-144.

Mohan M, Nair S, Bhagwat A and Krishna TG (1997). Genome mapping, molecular markers and marker-assisted selection in crop plants. Mol. Breed. 3: 87-103.

Murray MG and Thompson WF (1980). Rapid isolation of high molecular weight plant DNA. Nucleic Acids Res. 8: 43214325.

Powell W, Morgante M, Andre C and Hanafey M (1996). The comparison of RFLP, RAPD, AFLP and SSR (microsatellite) markers for germplasm analysis. Mol. Breed. 2: 225-238.

Qi X and Lindhout P (1997). Development of AFLP markers in barley. Mol. Gen. Genet. 254: 330-336.

Rafalski JA and Tingey SV (1993). Genetic diagnostics in plant breeding: RAPDs, microsatellites and machines. Trends Genet. 9: 275-280.

Röder MS, Plaschke J, König SU, Börner A, et al. (1995). Abundance, variability and chromosomal location of microsatellites in wheat. Mol. Gen. Genet. 246: 327-333.

Thomas CM, Vos P, Zabeau M, Jones DA, et al. (1995). Identification of amplified restriction fragment polymorphism (AFLP) markers tightly linked to the tomato Cf-9 gene for resistance to Cladosporium fulvum. Plant J. 8: 785-794.

Vos P, Hogers R, Bleeker M, Reijans M, et al. (1995). AFLP: a new technique for DNA fingerprinting. Nucleic Acids Res. 23: 4407-4414.

Wilson JA and Ross WM (1962). Cross-breeding in wheat, Triticum aestivum L. II. Hybrid seed set on a cytoplasmic male-sterile winter wheat composite subjected to cross-pollination. Crop Sci. 2: 415-417.

Zabeau M and Vos P (1993). Selective restriction fragment amplification: a general method for DNA fingerprinting. European Patent Application number 92402629.7; Publication number $0534858 \mathrm{Al}$. 